\title{
Low Blood Pressure and Haquapathy (Haqua Revitalize Therapy-HART)
}

\section{Faris AlHajri-PhD(AM)*}

Founder of Haquapathy, Haqua Wellness, VA, USA

*Corresponding Author: Faris AlHajri-PhD(AM), Founder of Haquapathy, Haqua

Wellness, VA, USA.
Received: March 23, 2021

Published: April 12, 2021

(C) All rights are reserved by Faris

AlHajri-PhD(AM).
Low blood pressure occurs when blood pressure is much lower than normal. This means the heart, brain, and other parts of the body do not get enough blood. Normal blood pressure is mostly between 90/60 mmHg and 120/80 mmHg.

Certain medicines and substances can lead to low blood pressure, including: alcohol, anti-anxiety, medicines, certain antidepressants, diuretics, heart medicines, including those used to treat high blood pressure and coronary heart disease, medicines used for surgery, painkillers. Other causes of low blood pressure include: nerve damage from diabetes, changes in heart rhythm (arrhythmias), not drinking enough fluids (dehydration), and heart failure [1].

\section{HART effects to low blood pressure}

HART reinstates the heart and the brain to function by improving the circulatory system by vasodilation and allow enough blood flow to both the heart and the brain, which have been affected by not getting enough blood flow, a reason behind low blood pressure.

To make it clearer, HART provides all the Four Essential Elements of Life (FEELs) to the circulatory system, namely; water, oxygen, hydrogen, and energy, all at the same time. Water maintains proper hydration to the cells, oxygen is supplied to the cells through the red blood cells that are contained within the hemoglobin, while hydrogen engages the electrons to become active.

Biochemist AlbertSzent-Györgyi discovered that hydrogen, rather than oxygen, was the fuel of life. Mankind needs oxygen to exist, but oxygen's counterpart (hydrogen) is the real fuel. Oxygen burns hydrogen, releasing the energy (in the form of ATP) that runs our bodies. Water supplies both the fuel (hydrogen) and the fire(oxygen), but hydrogen is often the limiting factor [2].
Heat is the natural source of our body's energy, whether you live in the coldest place on earth with the temperature at -50 degree Celsius, or the hottest place with the temperature reaching 50 degree Celsius, your body's temperature always remains steady during normal conditions at around 36.5-37 degrees Celsius (97.798.6 degrees Fahrenheit).

In a cold environment, the body will cause vasoconstriction (constriction of the blood vessels) to prevent loss of heat. On the contrary, in hot environment, it causes vasodilation or vasodilatation (dilation of blood vessels) to remove excessive heat from the body by means of sweating and perspiration.

When a person dies, the cells also die, as the body's temperature is dropped, and the energy is totally lost. The blood which consists of lipids (fats), and other substances, such as glucose (blood sugar), proteins, white blood cells and red blood cells, etc. become stagnant due to the sudden drop of the body's temperature at the time of permanent death.

To maintain healthy cells, the body's immune system remains steadily at high temperature as stated.

Our personal extensive studies we have conducted since we discovered Haqua Revitalize Therapy (HART) in August 2007, we found that the human body maintains its continuum energy for the reproduction of cells, metabolism, blood circulation, proper neurosystem of the brain and every a single part of the organ, we have the inner core of the body where energy is produced, particularly inside the stomach, we concluded the temperature stands at 40 degrees Celsius (104 Degree Fahrenheit) or above. This hypothesis we have concluded, also applies to the amniotic sac which is filled 
up with amniotic fluid inside the mother's womb where the fetal growth takes place without any exemption with regards to whoever the person may be or may belong, the temperature stands higher. Thus, amniotic fluid is with no single doubt, concluded as "Haqua”, simply 'Hot Water'.

Haqua Revitalize Therapy (HART) naturally enriches the body's internal energy by effortlessly transferring the heat in the form of energy from the Haqua to our bodies through the Therapeutic Methods of Haqua Gulping (TMHG) exclusively by hydration, there is no other means to shift energy to the body by hydration, whereas exercising, sunbathing, and other forms of heat-inducing therapies, do differently, thus, transferring the energy to the body but leading to dehydration where the body loses fluids (water). This would certainly lead to health effects in a long period of time when the body is overexposed to the sun, or excessive exercise, due to frequent body's dehydration, and lack of hydrogen inside the hydrogen pools, which was found to have tremendous health benefits regarding aging, chronic diseases, etc.

This principle can easily be referred to as the First Law of Thermodynamics states that heat is a form of energy, and thermodynamic processes (the branch of science concerned with heat and temperature and their relation to energy and work) are therefore subject to the principle of conservation of energy. This means that heat energy cannot be created or destroyed. It can, however, be transferred from one location to another and converted to and from other forms of energy. Thus, energy only transfers from hot bodies to cold bodies, making the reason behind our recommendation to abide with the temperature of Haqua for Gulping at around 50 degree Celsius (122 degree Fahrenheit) for adults and around 40 degree Celsius (104 degrees Fahrenheit) for babies up to children below 14 years old.

Haquation, which is completely different to hydration, it allows the body to absorb all the Four Essential Elements of Life (FEELs).

\section{Therapeutic Methods}

Implementing the Therapeutic Methods of Haqua Gulping (TMHG), shall be necessary to regularize the blood pressure back to its initial state, as follow.

Haqua Common Gulping Method (HCGM) [glass size $500 \mathrm{ml}$ (17 oz)] - For Adults

- $\quad$ One glass upon waking and on a 'clean' mouth* - at a standing position. *
- One glass between 7:00-10:00 a.m.

- $\quad$ One glass 15-30 minutes before lunch. **

- One glass between 2:00-4:00 p.m.

- $\quad$ One glass in the evening, 15-30 minutes before dinner. **

- $\quad$ One glass an hour before sleep. ${ }^{* *}$

\section{Notes}

- $\quad$ *Haqua should be taken before brushing teeth, mouthwash, or eating anything.

- $\quad$ ** Should be given high consideration. Haqua will detoxify the body, removing toxins which are in form of gases (Carbon Dioxide- $\mathrm{CO}_{2}$, Hydrogen Sulfide- $\mathrm{H}_{2} \mathrm{~S}$, Nitrogen-N, and Methane$\mathrm{CH}_{4}$ ).

- $\quad$ The daily recommended consumption of Haqua (Hot Water) is a minimum of 3 liters (101 oz) and maximum of 4 liters (135 oz).

- $\quad$ The water volume taken should not exceed $500 \mathrm{ml}$ (17 oz) at one time, and a maximum of 1 liter in the span of an hour.

- Shall abide with the recommended temperature of Haqua, fixed at around $50^{\circ} \mathrm{C}\left(122^{\circ} \mathrm{F}\right)$, a little bit less than the temperature of hot tea or hot coffee.

\section{Bibliography}

1. "Low blood pressure". MedlinePlus NLM (2021).

2. “Dancing with water. Hydrogen: Fuel of Life" (2016).

\section{Assets from publication with us}

- Prompt Acknowledgement after receiving the article

- Thorough Double blinded peer review

- Rapid Publication

- Issue of Publication Certificate

- High visibility of your Published work

Website: www.actascientific.com/

Submit Article: www.actascientific.com/submission.php

Email us: editor@actascientific.com

Contact us: +919182824667 